\title{
Retrospective Study on the Incidence of Thyroid Disorders in Bisha and Evolving Surgical Management Considerations
}

\author{
Dauda Bawa $^{1^{*}}$ (D), Saleem Khan ${ }^{1}$ (D), Yasser Khalifa ${ }^{1}$ (D), Shashi Prabha Sharma ${ }^{2}$ (D), Amal \\ Alghamdi ${ }^{1}$ (D), Hanan Albishi ${ }^{1}$ (i) and Nasser Al Tufail ${ }^{1}$ (D)
}

${ }^{1}$ Department of Surgery, King Abdullah Hospital Bisha, Saudi Arabia

${ }^{2}$ Department of Pathology, King Abdullah Hospital Bisha, Saudi Arabia

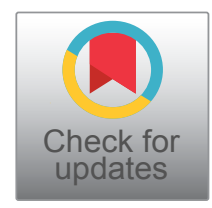

*Corresponding author: Dauda Bawa, Department of Surgery, King Abdullah Hospital Bisha, 67714, Asir Province, Saudi Arabia, Tel: +966553287972

\begin{abstract}
Background: There is a high prevalence of goiter in Bisha despite more than 15 years of the national campaign for increased dietary iodine supplementation. The cause is multifactorial. It is associated with non-neoplastic and neoplastic conditions. Surgical management has evolved over many years.
\end{abstract}

Purpose: To describe the pathological types of goiter in Bisha along with their management and to discuss current surgical considerations.

Methodology: A retrospective review of 339 patients with goiter diagnosed by FNAC and or histopathological examination and managed surgically or non-surgically.

Results: There were 339 patients, of which 280 (82.6\%) were females and $59(17.4 \%)$ males. Age range was seven to 94 years with a mean of $39.18 \pm 13.87$ years. There were $138(40.7 \%)$ multinodular goiters, $82(24.2 \%)$ colloid goiters, 8 diffuse goiters $(2.4 \%), 40(11 \%)$ solitary thyroid nodules, 10 thyroid nodules $(2.9 \%), 14$ thyroid cysts $(4.1 \%)$, 20 Hashimoto's thyroiditis $(5.9 \%)$ and two de Quervain's thyroiditis $(0.6 \%)$. Benign thyroid neoplasms comprised of $25(7.4 \%)$ follicular adenomas and $11(3.2 \%)$ Hürthle cell adenomas. Malignant thyroid disorders consisted of 18 $(5.3 \%)$ papillary thyroid cancers, $7(2.1 \%)$ mixed papillary/ follicular thyroid cancers, one $(0.3 \%)$ mixed follicular/ papillary thyroid cancer, and three $(0.9 \%)$ follicular thyroid cancers respectively. There were 128 (37.1\%) total thyroidectomies, $70(20.6 \%)$ hemithyroidectomies, 10 $(2.9 \%)$ subtotal thyroidectomies and, $5(1.5 \%)$ near-total thyroidectomies. There were 125 (36.9\%) patients who had no surgery. The overall complication rate was $14.5 \%$.
Conclusion: Thyroid disorders are still prevalent despite years of dietary iodine supplementation campaigns. The rate of complications following total thyroidectomy is significant and guidelines are changing

\section{Keywords}

Thyroid disorders, prevalence, thyroidectomy, Bisha, Saudi Arabia

\section{Introduction}

Goitre is common in the Southwestern region of Saudi Arabia where Bisha is located, in the longest valley of the Arabian Peninsula, standing at an altitude of approximately 610 meters (2,000 ft.) above sea level. In fact, recent studies have shown that Asir region Province (where Bisha is located) has the highest prevalence of goiter in Kingdom of Saudi Arabia (KSA) [1-4]. This is associated with a variety of pathologic conditions including thyroiditis, endocrine dysregulation, autoimmune disease and neoplasia. Many factors may account for this rate. An obvious factor is iodine deficiency which has been found to correlate with a proportionate increased prevalence and severity of the disease. A study of 3046 schoolchildren's urinary iodine content in 2015 found that iodine deficiency was still prevalent and endemic (more than $23 \%$ of the number studied) in the Asir region [4]. This was despite a universal iodization of salt started in 1997 in the Kingdom. The recommended dietary iodine salt in

Citation: Bawa D, Khan S, Khalifa Y, Sharma SP, Alghamdi A, et al. (2021) Retrospective Study on the Incidence of Thyroid Disorders in Bisha and Evolving Surgical Management Considerations. Int J Surg Res Pract 8:130. doi.org/10.23937/2378-3397/1410130

Accepted: September 28, 2021; Published: September 30, 2021

Copyright: (C) 2021 Bawa D, et al. This is an open-access article distributed under the terms of the Creative Commons Attribution License, which permits unrestricted use, distribution, and reproduction in any medium, provided the original author and source are credited. 
KSA is between 70 and 100 ppm as potassium iodate, even though this is higher than the WHO recommended level of $15-40 \mathrm{ppm}$ [5-7]. A recent National study shows that only $61.8 \%$ of the Asir population studied use recommended iodized salt in cooking [8].

The salt content of the soil is also correlated to incidence of goiter where high salt content may be goitrogenic despite iodination of table salt. There are several studies carried out in some regions of Saudi Arabia that reported the presence of high calcium in drinking water and concluded that some samples were not suitable for human consumption [9]. Alqahtani, et al. recently published a study of the soil characteristic in Bisha which demonstrated "very hard" water in 92\% of the samples studied with major elements $(\mathrm{Na}, \mathrm{Mg}$, and $\mathrm{Ca}$ ) exceeding the guideline limits of WHO in some samples [10]. Hard water contains mainly calcium or magnesium carbonate. Calcium is goitrogenic.

The role of nitrates, as environmental pollutants, in thyroid carcinogenesis is generating increasing interest recently. Nitrates commonly contaminate water and food as they are used as fertilizer in nitrate-rich manure. This may lead to high amounts present in fruits and vegetables, especially those grown in greenhouses. Nitrate competitively inhibits iodide uptake at the sodium-nitrate symporter and, by so doing, prevents the uptake of iodine by the thyroid gland. They are competitive inhibitors to iodine and may generate $\mathrm{N}$-nitroso-compounds which are carcinogenic. It has been implicated in the aetiopathogenesis of differentiated thyroid cancer [11]. In recent decades, differentiated thyroid cancer (DTC) incidence has been increasing worldwide. It is the second most common cancer among women in Saudi Arabia $[12,13]$.

Currently, the diagnosis of a thyroid mass is by FNAC which in the hands of an experienced thyro-cytologist, accurately categorizes the histological types in over $90 \%$ of samples [14-17]. FNAC helps to determine the nature of a thyroid mass and to diagnose malignancy preoperatively. However, it can be a subjective area of diagnosis and subject to different interpretations.

The commonest reason for thyroidectomy is cosmesis but fear of malignancy is the basis for some patients to seek surgical intervention. Ideally, the extent of thyroid resection should determine by the reason for the surgery. Recurrence, problems with reoperation and need for completion thyroidectomy if incidental thyroid cancer is found, have changed the behavior of surgeons towards favoring total thyroidectomy as procedure of choice when the entire gland is involved with disease or when there is malignancy. However, this practice needs to be evaluated by meta-analysis and clinical reviews.

King Abdullah Hospital Bisha has become strategic referral center in the southwestern region and receives many patients from the surrounding towns. A complication of thyroidectomy is one of the common cases resulting in litigation. We hereby conduct an epidemiological study to investigate the pathological types of thyroid disorders and their management, the incidence of complications and discuss current management considerations and strategies.

\section{Methodology}

Institutional approval was obtained from the ethical committee of King Abdullah Hospital. This is a retrospective study conducted in Surgery department of King Abdullah Hospital Bisha between December 2013 and December 2019. The clinical records of the patients were retrospectively reviewed, and a proforma was used to obtain information from the records that included demographic information, clinical features, methods used in diagnosis (Fine Needle Aspiration Cytology, thyroid ultrasound scan, CT scan of the neck, thyroid function test), type of treatment received (surgical or non-surgical), and result of postoperative histopathological examination of the resected thyroid gland.

\section{Subjects}

Data was collected from both sexes of all age groups. All patients with clinically confirmed goiter were included. Excluded from the study were subjects with inadequate specimen for diagnosis, and incomplete data or data acquisition errors. A final 339 patients were analyzed by the study (Figure 1 ).

\section{Demographic data}

A proforma was used to obtain the demographic data, and medical history of each patient. Demographic data included gender, age, and nationality.

\section{Laboratory measurements}

Total leukocyte count, thyroid function test, blood chemistry analyzed by a HITACHI automated biochemical analyzer (7600 HITACHI Ltd., Japan).

Total T4 (bound and free T4): 4.5-11.5 ug/dL; Free T4 (FT4): 0.8-1.7 ng/dL; T3 (Triiodothyronine) Free (serum): 0-6 years: $2.4-4.2 \mathrm{pg} / \mathrm{mL}$; 7-17 years: $2.9-5.1 \mathrm{pg} / \mathrm{mL}$; > 18-years-old: $2.3-4.2 \mathrm{pg} / \mathrm{mL}$; TSH: $0.3-5.0 \mathrm{U} / \mathrm{mL}$

\section{Thyroid scan}

The records of all thyroid ultrasound examination were reviewed as performed by certificated sonologists using a SonoScape X5 ultrasound device with 5-15 MHz L741 linear probe, and a GE LOGIQ device with 7-10 $\mathrm{MHz}$ linear probe. For this study, goiter is defined as a total volume greater than $18 \mathrm{~mL}$ in women and $25 \mathrm{~mL}$ in men [18].

\section{Statistics analysis}

The Statistical Package for Social Sciences (SPSS) version 26 was used to measure qualitative and 


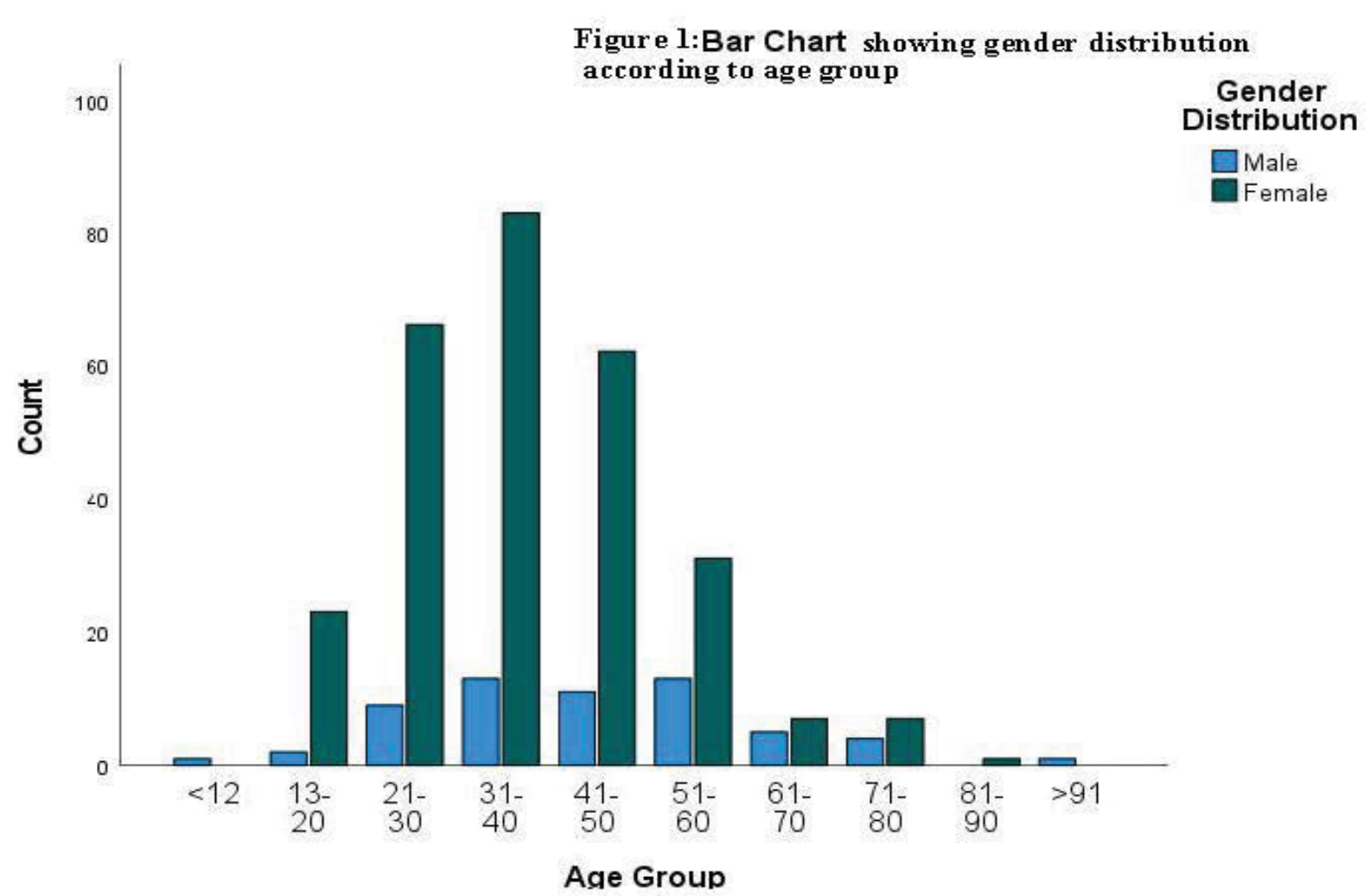

Figure 1: Gender \& Age distribution chart.

Table 1: Gender distribution according to age group.

\begin{tabular}{|c|c|c|c|c|c|}
\hline & & & \multicolumn{3}{|c|}{ Gender distribution } \\
\hline & & & Male & Female & Total \\
\hline \multirow{20}{*}{$\begin{array}{l}\text { Age } \\
\text { group }\end{array}$} & \multirow[t]{2}{*}{$<12$} & Count & & 0 & 1 \\
\hline & & $\%$ of Total & $0.3 \%$ & $0.0 \%$ & $0.3 \%$ \\
\hline & \multirow[t]{2}{*}{$13-20$} & Count & 2 & 23 & 25 \\
\hline & & $\%$ of Total & $0.6 \%$ & $6.8 \%$ & $7.4 \%$ \\
\hline & \multirow[t]{2}{*}{$21-30$} & Count & 9 & 66 & 75 \\
\hline & & $\%$ of Total & $2.7 \%$ & $19.5 \%$ & $22.1 \%$ \\
\hline & \multirow[t]{2}{*}{$31-40$} & Count & 13 & 83 & 96 \\
\hline & & $\%$ of Total & $3.8 \%$ & $24.5 \%$ & $28.3 \%$ \\
\hline & \multirow[t]{2}{*}{$41-50$} & Count & 11 & 62 & 73 \\
\hline & & $\%$ of Total & $3.2 \%$ & $18.3 \%$ & $21.5 \%$ \\
\hline & \multirow[t]{2}{*}{$51-60$} & Count & 13 & 31 & 44 \\
\hline & & $\%$ of Total & $3.8 \%$ & $9.1 \%$ & $13.0 \%$ \\
\hline & \multirow[t]{2}{*}{$61-70$} & Count & 5 & 7 & 12 \\
\hline & & $\%$ of Total & $1.5 \%$ & $2.1 \%$ & $3.5 \%$ \\
\hline & \multirow[t]{2}{*}{$71-80$} & Count & 4 & 7 & 11 \\
\hline & & $\%$ of Total & $1.2 \%$ & $2.1 \%$ & $3.2 \%$ \\
\hline & \multirow[t]{2}{*}{$81-90$} & Count & 0 & 1 & 1 \\
\hline & & $\%$ of Total & $0.0 \%$ & $0.3 \%$ & $0.3 \%$ \\
\hline & \multirow[t]{2}{*}{$>91$} & Count & 1 & 0 & 1 \\
\hline & & $\%$ of Total & $0.3 \%$ & $0.0 \%$ & $0.3 \%$ \\
\hline \multirow{2}{*}{\multicolumn{2}{|c|}{ Total }} & Count & 59 & 280 & 339 \\
\hline & & $\%$ of Total & $17.4 \%$ & $82.6 \%$ & $100.0 \%$ \\
\hline
\end{tabular}

quantitative variables. The quantitative variables like age and the qualitative variables like histopathological diagnosis were analyzed.

\section{Results}

Data from 354 patients' files were obtained. Of these, five patients had incomplete data, and 10 patients had FNAC results either with inadequate specimen collection or indeterminate diagnosis. Data from 339 patients were valid. Table 1 illustrates the age group and sex distribution of the patients studied. Of these, there were $280(82.6 \%)$ females and 59 (17.4\%) males resulting in a female/male ratio of 4.75:1. Age ranges from 7 to 94 years with a mean of $39.18 \pm 13.87$. There was only one $(0.3 \%)$ case of thyroid disorder below 12 years of age. The incidence of thyroid disorders rises from $7.4 \%$ (2 cases) in the age group 13-20, through $22.1 \%$ (75 cases) in the age group $21-30$ to peak at $28.1 \%$ (96 cases) in the age group 31-40. The incidence then drops from $21.5 \%$ (73 cases) in the age group 41-50, through $13.0 \%$ (44 cases) in the age group 51-60, 3.5\% (12 cases) in the age group $61-70$, and $3.2 \%$ (11 cases) in the age group $71-80$, to tail at $0.3 \%$ each in the age groups $81-90$ and above 90 , respectively. Most of the males were in the age groups $31-40(3.5 \%)$ and $51-60$ (3.5\%) while most females were in the age group $31-40$ (28.3\%). Distribution of patients according to their nationalities is shown in Table 2 . There were a total of 315 (92.9\%) Saudi nationals, out of which 49 (14.5\%) were males and 266 (78.5\%) were females, respectively. This was followed by Sudanese who numbered $6(1.8 \%)$ in total, with 2 females and 4 males, 
Table 2: Distribution by nationality and gender.

\begin{tabular}{|c|c|c|c|c|c|}
\hline & & & & der distr & \\
\hline & & & Male & Female & Total \\
\hline Distribution by Nationality & Saudi & Count & 49 & 266 & 315 \\
\hline & & $\%$ of Total & $14.5 \%$ & $78.5 \%$ & $92.9 \%$ \\
\hline & Indian & Count & 0 & 2 & 2 \\
\hline & & $\%$ of Total & $0.0 \%$ & $0.6 \%$ & $0.6 \%$ \\
\hline & Philipino & Count & 0 & 2 & 2 \\
\hline & & $\%$ of Total & $0.0 \%$ & $0.6 \%$ & $0.6 \%$ \\
\hline & Sri Lankan & Count & 0 & 1 & \\
\hline & & $\%$ of Total & $0.0 \%$ & $0.3 \%$ & $0.3 \%$ \\
\hline & Pakistan & Count & 0 & 1 & \\
\hline & & $\%$ of Total & $0.0 \%$ & $0.3 \%$ & $0.3 \%$ \\
\hline & Bangladeshi & Count & 0 & 1 & \\
\hline & & $\%$ of Total & $0.0 \%$ & $0.3 \%$ & $0.3 \%$ \\
\hline & Sudanese & Count & 4 & 2 & 6 \\
\hline & & $\%$ of Total & $1.2 \%$ & $0.6 \%$ & $1.8 \%$ \\
\hline & Yemeni & Count & 2 & 0 & 2 \\
\hline & & $\%$ of Total & $0.6 \%$ & $0.0 \%$ & $0.6 \%$ \\
\hline & Egyptian & Count & 3 & 0 & 3 \\
\hline & & $\%$ of Total & $0.9 \%$ & $0.0 \%$ & $0.9 \%$ \\
\hline & Ethiopian & Count & & 1 & 2 \\
\hline & & $\%$ of Total & $0.3 \%$ & $0.3 \%$ & $0.6 \%$ \\
\hline & Somalian & Count & 0 & 2 & 2 \\
\hline & & $\%$ of Total & $0.0 \%$ & $0.6 \%$ & $0.6 \%$ \\
\hline & Indonesian & Count & 0 & 1 & \\
\hline & & $\%$ of Total & $0.0 \%$ & $0.3 \%$ & $0.3 \%$ \\
\hline & Ethiopian & Count & 0 & 1 & 1 \\
\hline & & $\%$ of Total & $0.0 \%$ & $0.3 \%$ & $0.3 \%$ \\
\hline Total & & Count & 59 & 280 & 339 \\
\hline & & $\%$ of Total & $17.4 \%$ & $82.6 \%$ & $100.0 \%$ \\
\hline
\end{tabular}

Table 3: Pathologic type of goiter and thyroid status distribution.

\begin{tabular}{|c|c|c|c|c|c|}
\hline & & Toxic & Hypothyroid & Euthyroid & Total \\
\hline \multirow{13}{*}{$\begin{array}{l}\text { Pathologic type } \\
\text { count (\% of } \\
\text { Total) }\end{array}$} & Colloid goiter & $1(0.3 \%)$ & $9(2.6 \%)$ & $72(21.2 \%)$ & $82(24.1 \%)$ \\
\hline & Granulomatous thyroiditis (De Quervain') & $0(0.0 \%)$ & $0(0.0 \%)$ & $(0.6 \%)$ & $2(0.6 \%)$ \\
\hline & Hashimoto's thyroiditis & $0(0.0 \%)$ & $5(1.5 \%)$ & $15(4.4 \%)$ & $20(5.9 \%)$ \\
\hline & Diffuse hyperplasia & $4(1.2 \%)$ & $0(0.0 \%)$ & $14(1.2 \%)$ & $8(2.4 \%)$ \\
\hline & Mixed follicular/papillary & $0(0.0 \%)$ & $0(0.0 \%)$ & $1(0.3 \%)$ & $1(0.3 \%)$ \\
\hline & Thyroid cyst & $0(0.0 \%)$ & $1(0.3 \%)$ & $13(3.8 \%)$ & $14(4.1 \%)$ \\
\hline & Thyroid nodule & $0(0.0 \%)$ & $2(0.6 \%)$ & $18(2.3 \%)$ & $10(2.9 \%)$ \\
\hline & Multinodular goiter & $10(2.9 \%)$ & $12(3.5 \%)$ & $116(34.2 \%)$ & $138(40.6 \%)$ \\
\hline & Mixed papillary/follicular carcinoma & $0(0.0 \%)$ & $0(0.0 \%)$ & $17(2.1 \%)$ & $7(2.1 \%)$ \\
\hline & Hurtle cell adenoma & $0(0.0 \%)$ & $3(0.9 \%)$ & $18(2.3 \%)$ & $11(3.2 \%)$ \\
\hline & Papillary thyroid cancer & $0(0.0 \%)$ & $2(0.6 \%)$ & $16(4.7 \%)$ & $18(5.3 \%)$ \\
\hline & Follicular thyroid cancer & $0(0.0 \%)$ & $0(0.0 \%)$ & $(0.9 \%)$ & $3(0.9 \%)$ \\
\hline & Follicular adenoma & $0(0.0 \%)$ & $3(0.9 \%)$ & $2(6.5 \%)$ & $25(7.4 \%)$ \\
\hline \multicolumn{2}{|l|}{ Total N (\%) } & $15(4.4 \%)$ & $37(10.9 \%)$ & $87(84.7 \%)$ & $339(100 \%)$ \\
\hline
\end{tabular}


Table 4: Distribution of Clinical features of goiters seen in Bisha.

\begin{tabular}{|l|l|l|l|l|}
\hline & Frequency & Percent $^{*}$ & Valid percent & Cumulative percent \\
\hline Obstruction & 10 & 2.9 & 2.9 & 100.0 \\
\hline Pain & 7 & 2.1 & 2.1 & 100.0 \\
\hline Solitary nodule & 40 & 11.8 & 11.8 & 100.0 \\
\hline Thyroid cyst & 14 & 4.1 & 4.1 & 100.0 \\
\hline Hypothyroidism & 37 & 10.9 & 10.9 & 100.0 \\
\hline Thyrotoxicosis & 15 & 4.4 & 4.4 & 100.0 \\
\hline Total & 12.3 & 36.3 & 36.3 & 100.0 \\
\hline
\end{tabular}

${ }^{*}$ Percentages are of total number.

Table 5: Type of operative management.

\begin{tabular}{|l|l|l|l|l|}
\hline & Frequency & Percent & Valid percent & Cumulative percent \\
\hline No operation & 125 & 36.9 & 36.9 & 37.2 \\
\hline Total thyroidectomy & 128 & 37.8 & 37.8 & 74.9 \\
\hline Subtotal thyroidectomy & 10 & 2.9 & 2.9 & 77.9 \\
\hline Near-total thyroidectomy & 5 & 1.5 & 1.5 & 79.4 \\
\hline Hemithyroidectomy & 70 & 20.6 & 20.6 & 100.0 \\
\hline Total & 339 & 100.0 & 100.0 & \\
\hline
\end{tabular}

Table 6: Complications following thyroidectomy.

Recurrences-7 (11.43\%) ${ }^{\mathrm{a}}$

Incidental thyroid cancers-3 $(0.9 \%)^{\mathrm{b}}$

Unilateral recurrent laryngeal nerve palsies -4 (1.9\%)

Hypocalcemia -16 (7.5\%)

Loss of voice (aphonia) -1 (0.5\%)

NB total number of thyroidectomies $=214$

aRecurrence following subtotal thyroidectomies and hemithyroidectomies; ' On histological examination of thyroid specimens postoperatively.

respectively. The remaining nationalities, consisting of Indians, Pakistanis, Sri Lankans, Bangladeshis, Filipinos, Egyptians, and Indonesians, made up less than $1 \%$ each of the total population, respectively. The distribution of thyroid pathologies is illustrated in Table 3. There were $138(40.7 \%)$ cases of multinodular goiters, $82(24.2 \%)$ cases of colloid goiter, 8 cases of diffuse goiters $(2.4 \%)$, there were 40 (11\%) solitary thyroid nodules, 10 cases of thyroid nodules (2.9), and 14 cases of thyroid cysts (4.1\%). Cases of inflammatory thyroid lesions consisted of 20 cases of Hashimoto's thyroiditis (5.9\%) and two cases of de Quervain's thyroiditis (0.6\%). There were a total of 65 neoplasms (19.17\%), of which there were 36 (10.6\%) benign and 29 (8.55\%) malignant lesions. Benign thyroid neoplasms presented as follicular adenomas in 25 (7.4\%) cases and Hürthle cell adenomas in 11 (3.2\%) cases. Of the malignant thyroid disorders, papillary thyroid cancer occurred in 18 (5.3\%) cases, mixed papillary/follicular thyroid cancers in 7 (2.1\%) cases, mixed follicular/ papillary thyroid cancers occurred in one $(0.3 \%)$ case, and follicular thyroid cancers occurred in three $(0.9 \%)$ cases, respectively. A total of 287 (84.7\%) patients were euthyroid, 15 (4.4\%) had toxic goiter and 37 (10.9\%) had hypothyroidism. Multinodular goiter patients presented with most of the symptoms of toxicity, 10 (2.9\%), and hypothyroidism, 12 (3.5\%). Other clinical features were obstruction in 10 (2.9\%) patients, and pain in seven (2.1\%) patients as illustrated in Table 4. The operation rate in the cohort was $63.1 \%$ (214 patients) as can be seen in Table 5. Of these, 128 (37.1\%) had total thyroidectomy, $70(20.6 \%)$ had hemithyroidectomy, 10 (2.9\%) had subtotal thyroidectomy and finally, and 5 (1.5\%) had near-total thyroidectomy. The remaining 125 (36.9\%) of the patients had no surgery. The overall complication rate was $14.5 \%$. Complications after subtotal and hemithyroidectomies for benign thyroid diseases included seven recurrences $(11.43 \%)$, three incidental thyroid cancers $(0.9 \%)$, four unilateral recurrent laryngeal nerve palsies (1.9\%), and complications following total thyroidectomies were 16 hypocalcemia (7.5\%) cases and one case of loss of voice or aphonia (0.5\%) as shown in Table 6.

\section{Discussion}

Thyroid diseases can be described as either neoplastic or non-neoplastic, benign, or malignant lesions. They may present clinically as diffuse, multinodular, or solitary thyroid nodule, functionally as euthyroid, hypothyroid or hyperthyroid disorders. Their evaluation is important because most can be managed surgically or medically. Al Ghamdi, et al. studied 100 cases following thyroidectomy in Bisha, and classified the disease based on post-operative histology [19]. Their study highlighted the specific types of thyroid disorders that were frequent indications for thyroidectomy in the Bisha region. In this review, we studied the data of all patients that presented with thyroid disorder. Our aim was to analyze the histological pattern of thyroid diseases managed 


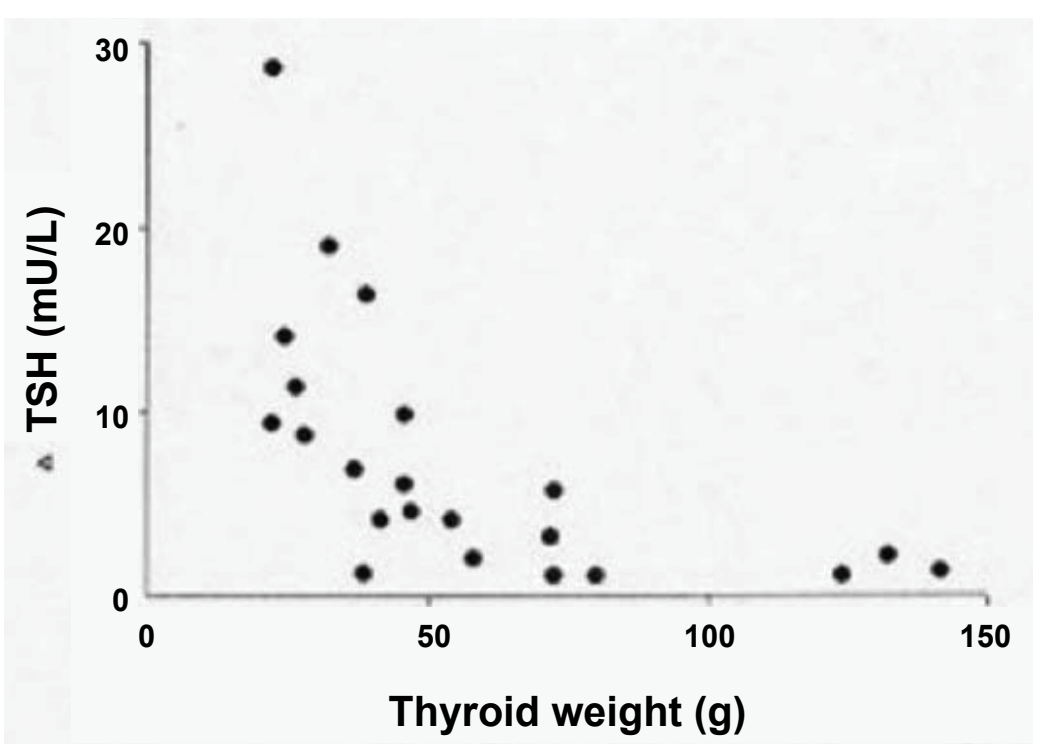

Figure 2: The relationship of TSH and thyroid weight $(\mathrm{g})$ in patients with clinically euthyroid multinodular goiter.

in Bisha region and to discuss the current guidelines of surgical management in the literature.

The highest incidence of thyroid disorders occurred in females aged between 31 and 40 (28.3\%). This correlates with findings in other studies within and outside Saudi Arabia [20-23]. Male to female ratio varies widely from country to country and region to region. The Male: Female ratio in our study was 1:4.75, similar to 1:4.5 reported by Ghafoor, et al. from Pakistan [24] and 1:4.74 from Bangladesh, Rahman, et al. [25] Ratios have been reported from 1:2.5 in Pakistan, Fahim, et al. [26] or 1:2.7 in Madinah, Albasri, et al. [23] to 1:7.9 in Zambia, Mirzakarimov, et al. [27].

The most frequent thyroid disorder was multinodular goiter $(40.7 \%)$. This was followed by colloid goiter (24.1\%). In the study by Al Ghamdi, et al. multinodular goiter (MNG) made up 31\% of the bulk of indications for thyroidectomy in Bisha [19]. Our finding correlates with reports of higher incidence of MNG from other studies, namely $43 \%$ from Asir, Abu-Eshy, et al. [28], 80\% from Riyadh, Raddaoui, et al. [20], 76.1\% from Jeddah, Qureshi, et al. [22], 31.4\% to $45.0 \%$ in a Malaysian study, Othman [29], 36.8\% in Western KSA, Salama, et al. [30], 62.8\% from Yemen, Al-Hureibi, et al. [31], from Turkey 42\%, Aydin, et al. [32] and, from Poland 57\%, Marcinkowska, et al. [33]. Nodules in a thyroid gland may represent growth and fusion of colloid filled follicles, which may be felt by palpation when they are up to $1 \mathrm{~cm}$ in diameter or located on the surface of the gland. They may also be discreet adenomatous growths or cysts. The prevalence of nodular goiter is directly proportional to the degree of iodine deficiency in a community [34]. As conceptualized by David Marine, the thyroid, in response to decreased iodine deficiency or increased TSH stimulation goes into a period of hyperplasia but eventually because of iodide repletion, enters into a resting phase characterized by storage of colloid giving rise to a colloid goiter; this cycle repeats itself many times giving rise to a nontoxic multinodular goiter [35]. Figure 2 illustrates the relationship of TSH and thyroid weight $(\mathrm{g})$ in patients with clinically euthyroid multinodular goiter.

Other studies reported a reverse pattern of incidence between colloid goiter and multinodular goiter. Albasry, et al. reported that colloid goiter was more prevalent (58.2\%) than multinodular goiter in their series in AlMadina region [23]. Ngadda, et al. reported a similar high prevalence (75\%) of colloid goiter in Nigeria [36]. The reason for the variation in prevalence between MNG and colloid goiter may be multifactorial. Shao, et al. reported a significant increase of non-toxic MNG prevalence in Shandong, a littoral region where there is high dietary/salt iodine content [37]. Similarly, Multiple studies have reported higher incidences of toxic adenoma in iodine-deficient areas and non-toxic multinodular goiter in iodine-excess or iodine sufficient areas [38-41].

The overall incidence of toxic goiter in our study was $7.09 \%$ (24/339). There were 16 cases of toxic MNG $(4.72 \%)$ and eight cases of diffuse toxic goiter $(2.36 \%)$. We did not record any case of toxic adenoma in this study. A similar rate (7.7\%) was recorded by Abu-Eshy, et al. in Asir region [28]. Iodine supplementation was shown to reduce the prevalence of thyrotoxicosis in six European countries, Reinwein, et al. [42]. Areas of iodine deficiency without dietary supplementation, on the other hand, have been shown to have high incidences of hyperthyroidism. Mengistu, et al. reported a $43.7 \%$ incidence of thyrotoxicosis in their study of 373 patients with thyroid disorders [43]. The thyroid gland tends to acquire autonomy in an environment of sustained iodine deficiency. Other factors may increase the predisposition of such promotion, including duration of exposure, age, and functional demand like number of childbirths, smoking and increased body mass index. On 
the other hand, hypothyroidism constituted $14.45 \%$ of our patients.

The incidence of malignancy was $8.55 \%$ which is lower than what was reported by many studies in Saudi Arabia, namely Kona \& Al-Mohareb (25\%) [44], Mofti, et al. (29\%) [45], Al-Tameem (21\%) [46], Nasr (14.5\%) [47] and Abu-Eshy (13.0\%) [28]. Papillary thyroid cancer predominated the malignant lesions in this study which is similar to findings in most other studies [12]. However, we did not record any cases of medullary, anaplastic and Hürthle cell cancers or lymphoma in our series. Al Ghamdi [19] (Bisha, 2002) and Al Amri [48] (Eastern Province, KSA, 2012) similarly did not report any cases of medullary thyroid carcinoma (MTC) in their series. This could be due to underdiagnosis, relative low prevalence of malignancy in Bisha or genetic differences compared to other populations. It is most likely due to its rarity in Saudi Arabia. Alzahrani and co-workers studied 629 cases of thyroid cancer in Saudi Arabia and found only $14(2.2 \%)$ cases of MTC [49].

The overall complication rate in our study was $14.5 \%$. The recurrence rate following subtotal thyroidectomy and hemithyroidectomy/lobectomy was $11.43 \%$. A recurrence rate of $43 \%$ has been reported after a 30 year follow up [50]. There were three cases of completion thyroidectomy in our study (Table 6), after the surgical specimens were reported to contain cancer, thus, giving an incidental cancer rate of $0.9 \%$. In a retrospective study involving 2592 patients, comparing total thyroidectomy and subtotal thyroidectomy, Tezelman, et al. found a significant increase incidence of completion thyroidectomy in the latter with no difference in permanent complications between the two procedures [51]. The incidental thyroid carcinoma rate was $7.2 \%$ in the two groups. Maturo, et al. in Italy, studied 1793 post-thyroidectomy specimens and found a $4.6 \%$ incidental thyroid cancer rate [52]. Pezzola, et al. also found an incidental thyroid cancer rate of $18.2 \%$ out of 165 patients operated for benign disease [53]. Wang, et al. report that 147 (20.7\%) of 709 thyroid cancer specimens were incidentally diagnosed intraoperatively or on postoperative pathological examination [54]. Pagni, et al. found that $45.2 \%$ of 287 papillary thyroid cancer cases were incidentally diagnosed following thyroidectomy [54]. For Woolner, et al. it was 59\% [55]. In a randomized clinical trial spanning 10 years, and involving 526 patients, recurrent goiter was found in $0.6 \%$ total thyroidectomy compared to $8.6 \%$ in Dunhill operation and $22.4 \%$ in bilateral subtotal thyroidectomy ( $p<0.001)$, and completion thyroidectomy was necessary in $0.6 \%$ total thyroidectomy compared to $2.8 \%$ in Dunhill operation and $8.0 \%$ in bilateral subtotal thyroidectomy patients ( $p<0.001$ ) $[56,57]$. Any permanent morbidity present at 10 years showed no significant difference in that study.

There was a long-drawn debate concerning the extent of thyroid tissue removed during thyroidectomy, regardless of whether the surgery was done for benign or malignant condition. Lobectomy and subtotal thyroidectomy were traditionally favored over total thyroidectomy because it was believed that the incidence of recurrent laryngeal paralysis and inadvertent parathyroid injury were less in the former procedures. However, the possibility of recurrence and the need for a completion thyroidectomy if the final histology is cancer, are important considerations. For these reasons, the 2016 guidelines and meta-analysis recommended total thyroidectomy for both toxic and non-toxic benign multinodular goiter [58,59]. Total thyroidectomy can now be performed as safely as lobectomy and subtotal thyroidectomy are performed, because of improved surgical techniques and experience $[50,60]$. The aim is to perform a safe total thyroidectomy, abolish risk of recurrence and future need for completion thyroidectomy if the final diagnosis was thyroid cancer.

While many surgeons reported similar complication rates for both total thyroidectomy and lobectomy/ subtotal thyroidectomy [61-64], others reported finding increased complication rates with total thyroidectomy [65-67]. This has recently raised questions over the preferred practice of total thyroidectomy [65]. Moreover, there is evidence that the true incidence of hypothyroidism following total thyroidectomy is underestimated [68]. Lorente-Poch and colleagues have outlined in detail, the reasons behind underestimation of the incidence of hypothyroidism in many studies [69]. Some of the reasons they adduced included a variety of laboratory ranges for normocalcemia and reference values, timing of blood sampling in the postoperative period and short/incomplete follow up. In a recent systematic review and meta-analysis, the reported incidence of hypothyroidism following total thyroidectomy is $19-38 \%$ and $0-3 \%$ respectively [70]. As a result, the updated American Thyroid Association guidelines on thyroid nodules and differentiated thyroid cancer has suggested lobectomy or subtotal thyroidectomy as alternatives to total thyroidectomy $[71,72]$. In their review, Dralle, et al. as far back as 2011, made a plea for individualizing extent of thyroid tissue resected, instead of making total thyroidectomy a routine procedure, even for experienced surgeons for bilateral thyroid diseases [73].

\section{Conclusion}

In conclusion, the prevalence of thyroid diseases remains high in Bisha despite years of dietary iodination likely due to other factors. Complications of thyroidectomy remain significant. There is little evidence for recommending total thyroidectomy over subtotal thyroidectomy on overall consideration. Total thyroidectomy has reduced recurrence rate but may result in more frequent adverse events. There is need for more extensive randomized controlled trials focusing 
on surgeons' experience, volume of surgery and details of surgical techniques used.

\section{Fund/Grant Support}

None.

\section{Conflict of Interest}

No potential conflict of interest relevant to this article was reported.

\section{Author Contribution}

Conceptualization: Dauda Bawa, Saleem Khan, Yasser M Khalifa; Formal Analysis: Dauda Bawa; Investigation: Dauda Bawa, Saleem Khan; Methodology: Dauda Bawa, Saleem Khan, Yasser M Khalifa, Shahi S Prabha, Amal Alghamdi; Project Administration: Amal Alghamdi, Hanan Albishi, Nasser Al Tufail; Writing-Original Draft: Dauda Bawa, Yasser M Khalifa and Shashi S Prabha; Writing-Review \& Editing Saleem Khan, Amal Alghamdi, Hanan Albishi, Nasser Al Tufail.

\section{References}

1. Al Nuaim AR, Al Mazrou $Y$, Kamel M, AlAttas $O$, Al Daghari $\mathrm{N}$, et al. (1997) lodine deficiency in Saudi Arabia. Ann Saudi Med 17: 293-297.

2. Al Dakheel MH, Haridi HK, Al Bashir BM, Al Shingiti $A$ Al Shehri S, et al. (2016) Prevalence of iodine deficiency disorders among schoolchildren in Saudi Arabia: Results of a national iodine nutrition study. East Mediterr Health J 22: 301-308.

3. Alsanosy R, Gaffar A, Khalafalla H, Mahfouz M, Zaid A, et al. (2021) Current iodine nutrition status and progress toward elimination of iodine deficiency disorders in Jazan, Saudi Arabia. BMC Public Health 12: 1006.

4. Abbag FI, Abu-Eshy SA, Mahfouz AA, Al Fifi SA, El Wadie $\mathrm{H}$, et al. (2015) lodine-deficiency disorders in the Aseer region, south-western Saudi Arabia: 20 years after the national survey and universal salt iodization. Public Health Nutr 18: 2523-2529.

5. Food grade salt: GSO 1843:2007.

6. World Health Organization (2014) Fortification of foodgrade salt with iodine for the prevention and control of iodine deficiency disorders. Geneva.

7. World Health Organization (2007) Assessment of iodine deficiency disorders and monitoring their elimination: A guide for programme managers. Geneva.

8. Al Dakheel MH, Haridi HK, Al Bashir BM, AL Shangiti A, Al Shehri S, et al. (2018) Assessment of household use of iodized salt and adequacy of salt iodization: A crosssectional National Study in Saudi Arabia. Nutr J 17: 35.

9. Mallick J (2017) Hydrogeochemical characteristics and assessment of water quality in the Al- Saad Lake, Abha Saudi Arabia. Appl Water Sci 7: 2869-2882.

10. Alqahtani FZ, Saifedin YD, Yasir FA, Elkhaleefa AM, Brima El (2020) Assessment of major and trace elements in drinking groundwater in Bisha Area, Saudi Arabia. HJC 2020: 1-10.

11. Drozd VM, Branovan I, Shiglik N, Biko J, Reiners C (2018) Thyroid cancer induction: Nitrates as independent risk factors or risk modulators after radiation exposure, with a focus on the chernobyl accident. Eur Thyroid J 7: 67-74.

12. Al Shahrani A, El Metwally A, Al Surimi K, Bin Salih S, AI Saleh Y, et al. (2016) The epidemiology of thyroid diseases in the Arab world: A systematic review. JPHE 8: 17-26.

13. Sawka AM, Brierley JD, Tsang RW, Thabane L, Rotstein L, et al. (2008) An updated systematic review and commentary examining the effectiveness of radioactive iodine remnant ablation in well-differentiated thyroid cancer. Endocrinol Metab Clin North Am 37: 457-480.

14. Chieng JSL, Lee $\mathrm{CH}$, Karandikar AA, Goh JPN, Tan SSS (2019) Accuracy of ultrasonography-guided fine needle aspiration cytology and significance of non-diagnostic cytology in the preoperative detection of thyroid malignancy. Singapore Med J 60: 193-198.

15. Kaplan E, Angelos P, Applewhite M, Frederic M, Raymon HG (2015) Chapter 21 Surgery of the thyroid. In: Feingold KR, Anawalt B, Boyce A, Endotext. South Dartmouth (MA): MDText.com, Inc.

16. Sinna EA, Ezzat N (2012) Diagnostic accuracy of fine needle aspiration cytology in thyroid lesions. J Egypt Natl Canc Inst 24: 63-70.

17. Gupta M, Gupta S, Gupta VB (2010) Correlation of fine needle aspiration cytology with histopathology in the diagnosis of solitary thyroid nodule. J Thyroid Res 2010: 379051.

18. Zheng L, Yan W, Kong Y, Liang P, Mu Y (2015) An epidemiological study of risk factors of thyroid nodule and goiter in Chinese women. Int $\mathrm{J}$ Environ Res Public Health 12: 11608-11620.

19. Al Ghamdi SA, Raza MA, Hanif S, Al Shehri G (2002) The pattern of surgically treated thyroid diseases in the Bisha Region of Saudi Arabia. Ann Saudi Med 22: 410-412.

20. Raddaoui E, Zaidi SN (2015) Epidemiology and the histopathological pattern of diagnosis of thyroid diseases in a university hospital in Riyadh, Saudi Arabia. JHOR 1: $11-18$.

21. Sengupta S, Tuli IP, Baruah B, Kesari SP, llapakurty B, et al. (2014) Spectrum of goitrous lesions in patients at a tertiary care center of Sikkim. Sahel Med J 17: 112-116.

22. Qureshi IA, Khabaz MN, Baig M, Begum B, Abdelrehaman AS, et al. (2015) Histopathological findings in goiter: $A$ review of 624 thyroidectomies. Neuro Endocrinol Lett 36: 48-52.

23. Albasri A, Sawaf Z, Hussainy AS, Alhujaily A (2014) Histopathological patterns of thyroid disease in Al-Madinah region of Saudi Arabia. Asian Pac J Cancer Prev 15: 55655570.

24. Ghafoor A, Sajjad M, Akram M, Khan ZA (2015) Histopathological pattern of enlarged thyroid gland. Gomal J Med Sci 13: 207-210.

25. Rahman MA, Biswas MA, Siddika ST, Sikder AM, Talukder SI, et al. (2013) Histomorphological pattern of thyroid lesions. Dinajpur Med Col J 6: 134-140.

26. Fahim A, Qureshi A, Alvi H, Azmi MA (2012) Clinical presentation and evaluation of histopathological patterns of hospital-based frequency of thyroidectomic biopsies. Medical Forum 23: 28-31.

27. Mirzakarimov F, Odimba BFK, Tembo P (2012) Patterns of surgically treated thyroid disease in lusaka, Zambia. Medical Journal of Zambia 39: 7-11.

28. Abu Eshy SA, Al Shehrimy MY, Khan AR, Khan GM, Al 
Humaidi MA, et al. (1995) Causes of goiter in Asir region: A histopathology analysis of 361 cases. Ann Saudi Med 15: 74-76.

29. Othman NH (2018) Multi-nodular thyroid goitre over a 10year period in Hospital Universiti Sains Malaysia; Is iodine deficiency addressed adequately in Kelantan, Malaysia? Clin Med 1: 1001.

30. Salama SI, Abdullah LS, Al Qahtani MH, Al Maghrabi JA (2009) Histopathological pattern of thyroid lesions in western region of Saudi Arabia. New Egypt J Med 40: 580585.

31. Al Hureibi KA, Abdulmughni YA, Al Hureibi MA, Al Hureibi YA, Ghafoor MA (2004) The epidemiology, pathology, and management of goitre in Yemen. Ann Saudi Med 24: 119123.

32. Aydin Y, Besir FH, Erkan ME, Yazgan O, Gungor A, et al. (2014) Spectrum and prevalence of nodular thyroid diseases detected by ultrasonography in the Western Black Sea region of Turkey. Med Ultrason 16: 100-106.

33. Marcinkowska M, Sniecikowska B, Zygmunt A, Brzezinski J, Dedecjus M, et al. (2017) Postoperative hypoparathyroidism in patients after total thyroidectomy-retrospective analysis. Neuro Endocrinol Lett 38: 488-494.

34. Pinchera A, Aghini Lombardi F, Antonangeli L, Vitti P (1996) Multinodular goiter. Epidemiology and prevention. Ann Ital Chir 67: 317-325

35. Medeiros Neto G (2016) Multinodular goiter. In: Feingold KR, Anawalt B, Boyce A, Endotext. South Dartmouth (MA): MDTex.com, Inc.

36. NggadaHA, Ojo OS, Adelusola KO (2008)A histopathological analysis of thyroid diseases in Ile-ife, Nigeria. A review of 274 cases. Niger Postgrad Med J 15: 47-51.

37. Shao HJ, Li J, He XQ, Liu N, Li YH, et al. (2016) Prevalence of nontoxic nodular goiter after a nearly two-decade universal salt iodization in a littoral region of shandong province, CHINA. Acta Endocrinol 12: 43-46.

38. Tonacchera M, Führer D (2017) Toxic adenoma and multinodular toxic goiter. Vitti P, Hegedus L, Thyroid diseases. Endocrinology, Springer, 1-27.

39. Krohn K, Führer D, Bayer $Y$, Eszlinger M, Brauer V, et al. (2005) Molecular pathogenesis of euthyroid and toxic multinodular goiter. Endocr Rev 26: 504-524.

40. Belfiore A, Sava L, Runello F, Tomaselli L, Vignerit R (1985) Solitary autonomously functioning thyroid nodules and iodine deficiency. J Clin Endocrinol Metab 56: 283-287.

41. Laurberg $P$, Jørgensen $T$, Perrild $H$, Ovesen $L$, Knudsen $N$, et al. (2006) The Danish investigation on iodine intake and thyroid disease, DanThyr: Status and perspectives. Eur J Endocrinol 155: 219-228.

42. Reinwein D, Benker G, Konig MP, Pinchera A, Schatz $\mathrm{H}$, et al. (1988) The different types of hyperthyroidism in Europe. Results of a prospective survey of 924 patients. J Endocrinol Invest 11: 193-200.

43. Mengistu M (1993) The pattern of thyroid diseases in adult Ethiopians and experience in management. Ethiop Med $\mathrm{J}$ 31: 25-36.

44. Kona S, Al Mohareb A (1988) The surgery of goiter in Riyadh Armed Forces Hospital. Saudi Med J 9: 617-621.

45. Mofti AB (1991) Experience with thyroid surgery in the Security Forces Hospital, Riyadh. Saudi Medical Journal 12: $504-506$.
46. Al Tameem MM (1987) The pattern of surgically treated thyroid disease in two general hospitals in Riyadh. Saudi Med J 8: 61-66.

47. Nasr HA (1983) Surgically treated goiter at King Abdulaziz University Hospital, Jeddah, Saudi Arabia. $8^{\text {th }}$ Saudi Medical Conference, King Khalid Academy, Riyadh.

48. Al Amri (2012) Pattern of thyroid cancer in the eastern province of Saudi Arabia: University Hospital experience. J Cancer Therapy 3: 187-191.

49. Alzahrani AS, Alomar H, Alzahrani N (2017) Thyroid cancer in Saudi Arabia: A histopathological and outcome study. Int J Endocrinol 2017: 8423147.

50. Lang $\mathrm{BH}$ (2017) What should the correct extent of thyroidectomy be in a developing area where goiter is an endemic problem? Thyroid Disorders Ther 6: 1 .

51. Tezelman S, Borucu I, Senyurek Giles Y, Tunca F, Terzioglu $T$ (2009) The change in surgical practice from subtotal to near-total or total thyroidectomy in the treatment of patients with benign multinodular goiter. World J Surg 33: 400-405.

52. Maturo A, Tromba L, De Anna L, Carbotta G, Livadoti G, et al. (2017) Incidental thyroid carcinomas. A retrospective study. G Chir 38: 94-101.

53. Pezzolla A, Marzaioli R, Lattarulo S, Docimo G, Conzo G, et al. (2014) Incidental carcinoma of the thyroid. Int J Surg 12: 98-102.

54. Pagni F, Jaconi M, Delitala A, Garancini M, Maternini M, et al. (2014) Incidental papillary thyroid carcinoma: Diagnostic findings in a series of 287 carcinomas. Endocr Pathol 25: 288-296.

55. Woolner LB, Lemmon M, Beahrs OH, Black M, Keating FR (1960) Occult papillary carcinoma of the thyroid gland: A study of 140 cases observed in a 30 year period. J Clin Endocrinol 20: 89-105.

56. Barczyński M, Konturek A, Hubalewska Dydejczyk A, Gołkowski F, Nowak W (2018) Ten-year follow-up of a randomized clinical trial of total thyroidectomy versus dunhill operation versus bilateral subtotal thyroidectomy for multinodular non-toxic goiter. World J Surg 42: 384-392.

57. Marchesi M, Biffoni M, Tartaglia F, Biancari F, Campana FP (1998) Total versus subtotal thyroidectomy in the management of multinodular goiter. Int Surg 83: 202-204.

58. Moalem J, Suh I, Duh QY (2008) Treatment and prevention of recurrence of multinodular goiter: An evidence-based review of the literature. World J Surg 32: 1301-1312.

59. Sewefy AM, Tohamy TA, Esmael TM, Atyia AM (2017) Intracapsular total thyroid enucleation versus total thyroidectomy in treatment of benign multinodular goiter. A prospective randomized controlled clinical trial. Int J Surg 45: 29-34.

60. Vaiman M, Nagibin A, Hagag P, Buyankin A, Olevson J, et al. (2008) Subtotal and near total versus total thyroidectomy for the management of multinodular goiter. World J Surg 32: 1546-1551.

61. Hauch A, Al Qurayshi Z, Randolph G, Kandil E (2014) Total thyroidectomy is associated with increased risk of complications for low and high-volume surgeons. Ann Surg Oncol 21: 3844-3852.

62. Padur AA, Kumar N, Guru A, Badagabettu SN, Shanthakumar SR, et al. (2016) Safety and effectiveness of total thyroidectomy and its comparison with subtotal thyroidectomy and other thyroid surgeries: A systematic review. J Thyroid Res 2016: 7594615. 
63. Mauriello C, Marte G, Canfora A, Napolitano S, Pezzola A, et al. (2016) Bilateral benign multinodular goiter: What is the adequate surgical therapy? A review of literature. Int $J$ Surg 28: S7-S12.

64. Makay Ö (2017) Less than total thyroidectomy for goiter: When and how? Gland Surg 6: S49-S58.

65. Cirocchi R, Trastulli S, Randolph J, Guarino S, Di Rocco $\mathrm{G}$, et al. (2015) Total or near-total thyroidectomy versus subtotal thyroidectomy for multinodular non-toxic goiter in adults. Cochrane Database Syst Rev.

66. Edafe O, Antakia R, Laskar N, Uttley L, Balasubramanian SP (2014) Systematic review and meta-analysis of predictors of post-thyroidectomy hypocalcemia. $\mathrm{Br} \mathrm{J}$ Surg 101: 307-320.

67. Haugen BR, Alexander EK, Bible KC, Doherty GM, Mandel SJ, et al. (2016) 2015 American thyroid Association Management Guidelines for adult patients with thyroid nodules and differentiated thyroid cancer: The American thyroid Association Guidelines task force on thyroid nodule and differentiated thyroid cancer. Thyroid 26: 1-133.
68. Röjdmark J, Järhult J (1995) High long-term recurrence rate after subtotal thyroidectomy for nodular goitre. Eur J Surg 161: 725-727.

69. Lorente Poch L, Sancho JJ, Muñoz-Nova JL, Sánchez Velázquez P, Sitges Serra A (2015) Defining the syndromes of parathyroid failure after total thyroidectomy. Gland Surg 4: 82-90.

70. Ross DS, Burch HB, Cooper DS, Greenlee MC, Laurberg P, et al. (2016) American Thyroid Association Guidelines for diagnosis and management of hyperthyroidism and other causes of thyrotoxicosis. Thyroid 26: 1343-1421.

71. Hartl DM, Guerlain J, Breuskin I, Hadoux J, Baudin E, et al. (2020) Thyroid lobectomy for low to intermediate risk differentiated thyroid cancer. Cancers 12: 3282.

72. Addasi N, Fingeret A, Goldner W (2020) Hemithyroidectomy for thyroid cancer: A review. Medicina 56: 586.

73. Dralle H, Lorenz K, Machens A (2011) State of the art: Surgery for endemic goiter-a plea for individualizing the extent of resection instead of heading for routine total thyroidectomy. Langenbecks Arch Surg 396: 1137-1143. 